\title{
Corrigendum: Biological Control Agents Against Fusarium Wilt of Banana
}

\author{
Giovanni Bubici $^{1 *}$, Manoj Kaushal ${ }^{2}$, Maria Isabella Prigigallo', \\ Carmen Gómez-Lama Cabanás ${ }^{3}$ and Jesús Mercado-Blanco ${ }^{3}$ \\ ${ }^{1}$ Consiglio Nazionale delle Ricerche (CNR), Istituto per la Protezione Sostenibile delle Piante (IPSP), Bari, Italy, ${ }^{2}$ International \\ Institute of Tropical Agriculture (IITA), Dar es Salaam, Tanzania, ${ }^{3}$ Department of Crop Protection, Institute for Sustainable \\ Agriculture (CSIC), Córdoba, Spain
}

Keywords: Musa acuminata, Fusarium oxysporum f. sp. cubense, Panama disease, soil microbiota, beneficial microorganisms, biocontrol

OPEN ACCESS

Approved by:

Frontiers Editorial Office,

Frontiers Media SA, Switzerland

*Correspondence:

Giovanni Bubici

giovanninicola.bubici@cnr.it

Specialty section:

This article was submitted to

Plant Microbe Interactions,

a section of the journal

Frontiers in Microbiology

Received: 02 May 2019

Accepted: 23 May 2019

Published: 11 June 2019

Citation:

Bubici G, Kaushal M, Prigigallo MI,

Gómez-Lama Cabanás $C$ and

Mercado-Blanco J (2019)

Corrigendum: Biological Control

Agents Against Fusarium Wilt of

Banana. Front. Microbiol. 10:1290.

doi: 10.3389/fmich.2019.01290

\section{A Corrigendum on}

\section{Biological Control Agents Against Fusarium Wilt of Banana}

by Bubici, G., Kaushal, M., Prigigallo, M. I., Gómez-Lama Cabanás, C., and Mercado-Blanco, J. (2019). Front. Microbiol. 10:616. doi: 10.3389/fmicb.2019.00616

In the original article, the reference for "Kalaiponmani et al., 2017" was incorrectly written as "Gopalakrishnan, V. (2017). Optimization of protein isolation and preliminary comparative proteomics of pathogenic Fusarium oxysporum f. sp. cubense (p-Foc) and non-pathogenic Fusarium oxysporum (np-Fo). J. Plant Pathol. 99, 361-369. doi: 10.4454/jpp.v99i2.3883"

It should be "Kalaiponmani, K., Thangavelu R., and Varun, G. (2017). Optimization of protein isolation and preliminary comparative proteomics of pathogenic Fusarium oxysporum f. sp. cubense (p-Foc) and non-pathogenic Fusarium oxysporum (np-Fo). J. Plant Pathol. 99, 361-369. doi: 10.4454/jpp.v99i2.3883"

The authors apologize for this error and state that this does not change the scientific conclusions of the article in any way.

Copyright (๑) 2019 Bubici, Kaushal, Prigigallo, Gómez-Lama Cabanás and Mercado-Blanco. This is an open-access article distributed under the terms of the Creative Commons Attribution License (CC BY). The use, distribution or reproduction in other forums is permitted, provided the original author(s) and the copyright owner(s) are credited and that the original publication in this journal is cited, in accordance with accepted academic practice. No use, distribution or reproduction is permitted which does not comply with these terms. 